\title{
ON THE FAILURE OF A LEGAL TRANSPLANT: THE CASE OF EGYPTIAN TAKEOVER LAW
}

\author{
Ahmad A. Alshorbagy* \\ Faculty of Law, Alexandria University
}

\section{INTRODUCTION}

In his seminal work on comparative law, Alan Watson outlined a theory of legal development based on the idea of legal transplants. ${ }^{1}$ According to Watson, legal transplants are the source for most global legal developments because the majority of changes in legal systems are the result of borrowing. ${ }^{2}$ Thus, the quality of legal rules is of little significance to the success of a transplant as the rules are not peculiarly designed for particular societies. Rather, the act of transplanting the rule is what really matters. ${ }^{3}$

This Article examines Egyptian takeover law derived from transplanted French law. ${ }^{4}$ This Article provides context by comparing Egyptian takeover law to its counterparts in three different Middle Eastern jurisdictions: Saudi Arabia, Bahrain, and Kuwait. ${ }^{5}$ These countries' securities markets are considered emerging markets in the Middle East, and they bear substantial resemblance to the Egyptian market in their corporate structure, political environments, and takeover regulations.

This Article's comparison sheds light on the role of legal transplants in takeover law by examining Egypt's takeover regulations as imported from France. While a transplant can be successful even if the borrowed rules are intended to serve a different purpose in the recipient jurisdiction than they did in the source jurisdiction, success depends on the existence of a functional legal and institutional infrastructure in the recipient jurisdiction that can amend the imported rules to make them compatible to their new legal environment. In this instance, Egypt did not have the necessary infrastructure to smoothly adopt the transplanted French takeover rules.

* S.J.D., LL.M., University of Virginia School of Law, Assistant Professor at Alexandria University School of Law in Egypt. This article is based on a portion of my doctoral thesis. I would like to thank Professor Julia Mahoney for her invaluable comments, Ms. Leslie Ashbrook and Ms. Sarah Withers for their editorial work, and my wife for her unconditional support. Of course, all errors remain mine. The author can be reached at aaa9f@virginia.edu or a_almoatassem@yahoo.com. 1993).

1. See Alan Watson, Legal Transplants: An Approach to Comparative Law (2d ed.

2. See id.

3. Id. at 94-96.

4. See infra Part II.

5. See infra Part III. 
Part Two defines legal transplants and draws guidelines for successful transplants. ${ }^{6}$ The most important factor for measuring the success of a transplant is the extent to which the imported rule serves the purpose for which it is transplanted. Success depends on the compatibility of the imported rules to the legal environment in which they were transplanted. The institutional and legal infrastructures of the recipient jurisdiction are the most significant factors. Part Two also examines the relationship between French and Egyptian laws. ${ }^{7}$ French law has been a key source for Egypt's legal development since the beginning of the codification of the Egyptian law. Thus, legal transplants have greatly contributed to Egyptian legal development not only on the individual rule level but also to the legal system in its entirety.

Part Three discusses the takeover rules of the European Union as the source of the French takeover regulations. ${ }^{8}$ France has partially adopted the European takeover rules as outlined in the Thirteenth Directive on Takeover Bids. ${ }^{9}$ This partial adoption, which negated the purpose of the Takeover Directive to encourage takeovers, is a result of the French desire to protect their national investments from takeover by international rivals. In contrast, the Egyptian takeover regulations seek to attract more investments and to encourage takeovers. Despite the fact that the objective of Egypt's takeover laws is starkly different from the French motivation, Egypt essentially copied the French takeover rules.

The Egyptian government failed to account for the varying motivations of French and Egyptian regulations. The Egyptian government should have anticipated the need for amendments necessary for the success of the takeover transplant. Egypt's institutional incompetence intensified the incompatibility of the transplant. This incompetence is evident in the dependency and inefficiency of the Egyptian Financial Supervisory Authority (EFSA), which is the main market regulator and supervisor in Egypt. ${ }^{10}$ The EFSA's ineffectiveness extends to its judicial supervision of capital market disputes. Furthermore, the failure of the imported laws from France to achieve Egypt's goal may also be attributed to the newness of Egypt's capital market laws and the jurisdictional conflict between Egyptian courts over their competence to hear takeover disputes.

The ineffective transplanting of the French takeover rules was also caused by Egypt's lack of a robust legal infrastructure. The Egyptian takeover regulations took the form of executive regulations for the Capital Market law. This format assumes that the Capital Market law provides guidelines for the implementation of such regulations. This is incorrect with respect to the

6. See infra Part II.

7. See infra Part II.

8. See infra Part III.

9. Council Directive 2004/25, 2004 O.J. (L 142) 12 (EC).

10. About EFSA, EGYPTIAN FIN. SUPERVISORY AUTH., http://www.efsa.gov.eg/content/ efsa2_en/efsa2_merge_about_en/efsa2_merge_efsa_en.htm (last visited Mar. 29, 2012). 
Egyptian Capital Market law. Unlike the French law or the Kuwaiti law, the Egyptian Capital Market law lacks any rule regulating takeovers. This raises doubts concerning the validity of the Egyptian takeover regulations. This weak legal infrastructure has resulted in many drawbacks in the Egyptian takeover regulations. Weaknesses include vagueness and poor drafting in some provisions of the regulations such as the price determination provision of the mandatory tender offer. ${ }^{11}$ Other examples of the regulations' shortcomings include the failure to add rules necessary to achieve the purpose of the regulations such as breakthrough and squeeze-out rules.

To further illustrate the inadequacy of the imported takeover regulations, Part Four examines the Mobinil case, the first takeover dispute raised in Egypt after the adoption of the new takeover regulations. ${ }^{12}$ In conclusion, this Article argues that the success of legal transplantation lies less in the substance of the rules than in building effective regulatory states that are able to adjust the imported rules to make them serve their needs. ${ }^{13}$

\section{THE LEGAL TRANSPLANT}

Although the Egyptian legal system is derived from the French system, the transplantation of the French takeover law in Egypt has been unsuccessful. This Part examines the parameters of legal transplants in general. It then moves on to explain the transplanting of the French legal system in Egypt with a focus on the transplantation of the French takeover regulations. This Part concludes with a discussion of the reasons for the failure of the transplantation of the takeover regulations in Egypt.

\section{A. Legal Transplant Parameters}

Legal transplantation is the most fertile source of legal development. ${ }^{14}$ Because so many laws are transplanted, it follows that "legal rules are not peculiarly devised for the particular society in which they operate and also that this is not a matter for great concern." 15 Transplantation provides accessible

11. Law No. 135 of 1993 (Executive Regulations of Capital Market Law), Al-Waqa'i' alMisriyah, 8 Apr. 1993, Vol. 81 F., art. 354 (Egypt) [hereinafter ERCML].

12. Case no. 12149/2010/Supreme Administrative Court (Egypt).

13. See infra Part III.D.3.b.

14. WATSON, supra note 1, at 95 ("[T]he contract of sale in the whole Western world, Common law countries and Civil law countries alike, is fundamentally that which existed at Rome in the later Second century A.D.").

15. Id. at 96. See also Alan Watson, Comparative Law and Legal Change, 37 CAMBRIDGE L.J. 313, 315-16 (1978) (arguing that it is the act of transplanting the law that matters most for the success of a transplantation). But see Hideki Kanda \& Curtis Milhaupt, Re-examining Legal Transplants: The Director's Fiduciary Duty in Japanese Corporate Law, 51 AM. J. COMP. L. 887, 890 (2003) (citing Pierre Legrand, What "Legal Transplants"?, in ADAPTING LEGAL Cultures 55 (David Nelken \& Johannes Feest eds., 2001); Otto Kahn-Freund, On Uses and 
and potentially fruitful sources of legal development. Such sources serve as an authority for practitioners involved with legal reform. Furthermore, legal transplanting is useful when a rule needs to be quickly developed. This form of transplantation, known as blind copying, is more common when the receiving country is less advanced legally. Because of the ease and speed with which they can be instituted, legal transplants are ubiquitous. ${ }^{16}$

The central question addressed in this Article is not related to the viability of legal transplants, but to the conditions for success of the transplant. Although there is no unified measurement to assess the success of transplants, a few conclusions can be drawn. ${ }^{17}$ For example, the motivation behind the transplant determines its success to a great extent. The adoption of any legal rule must have certain purposes. Legal drafters should be consulted to know the original purpose of the regulation. Transplantation is successful insofar as it actually fulfills its intended purposes in the host jurisdiction. ${ }^{18}$ Of course, the contemplated purposes of a legal transplant may be politically biased. ${ }^{19}$ Thus, focus should be placed on purposes related to public interests rather than private interests. It is the responsibility of legal practitioners to help elucidate the considerations that should prevail among the competing interests to determine the main purposes of the transplanted rules. However, the motivation alone remains an inexact criterion to assess the success of a legal transplant.

Other factors contribute to the success of a legal transplant; most important is the legal environment in which the rule is transplanted. In particular, the success of transplantation depends on its compatibility with the receiving country's preexisting legal and institutional infrastructure. ${ }^{20} \mathrm{~A}$ plant cannot properly grow unless it is transplanted in the right season and into soil

Misuses of Comparative Law, 37 MoD. L. REv. 1, 10-11 (1974); Ugo Mattei, Efficiency in Legal Transplants: An Essay in Comparative Law and Economics, 14 INT'L REV. L. \& ECON. 3, 8 (1994). A competing model for Watson's suggests that "[n]othing in the law is autonomous; rather, law is a mirror of society, and every aspect of the law is molded by economy and society." William Ewald, Comparative Jurisprudence (II): The Logic of Legal Transplants, 43 AM. J. COMP. L. 489, 492 (1995) (explaining the "mirror theories" have two aspects: the first is that the law reflects not only one factor but a set of factors constituting from geographic, religious, political factors, etc.; the second aspect is that rules of law also vary according to the strength of these factors). Id. at 492-93.

16. Kanda \& Milhaupt, supra note 15 , at 889 .

17. Id. at 890 .

18. Motivation is, however, an ongoing issue that may change over time. An unsuccessful transplantation today may be successful several years in the future. See id. at 891 .

19. For example, a monopolist businessman who is also politically influential may have a biased motivation that will affect the quality of the imported rules, if he is involved in regulating competition. In fact, this was the case with Egyptian competition law regulation. See infra note 88 and accompanying text.

20. See Kanda \& Milhaupt, supra note 15 , at 891 (describing these factors as the "fit" between the imported rule and the host environment. This "fit" has two components: (1) microfit refers to the relationship between the imported rule and the preexisting legal infrastructure in the host country; (2) macro-fit describes the relationship between the transplantation and the preexisting political economy institutions of the host country). 
well suited to its needs; the same idea applies to a legal rule.

\section{B. Transplanting the French Legal System in Egypt}

Egyptian law belongs to the Romano-Germanic family of law. ${ }^{21}$ The Romano-Germanic family includes countries whose legal systems are based on Roman ius civile, ${ }^{22}$ which originated in Europe and "has evolved primarily for historical reasons as a means of regulating private relationships between individuals." ${ }^{.23}$ Other branches of law were later developed according to the principles of civil law. Codification of legislation has become a distinctive feature of this family since the nineteenth century, and this, in turn, established its worldwide ubiquity. ${ }^{24}$

Under Mohammad Ali's reign, which started in 1805 and lasted until 1849, Egypt began the modernization of its laws to become a civil law country. ${ }^{25}$ The transformation from Shari'a law to civil law started with establishing specialized judicial councils in response to Egypt's gradually increasing subjection to international commerce constraints and Western imperialist influence. These judicial councils progressively limited the competence of Shari'a courts in most of the matters unrelated to personal status. The Mixed Courts were established in 1875 to handle disputes involving foreign nationals, while the National Courts heard disputes between Egyptians. ${ }^{26}$

Although Egypt was part of the Ottoman Empire at that time, strong Western influences persuaded Egypt not to adopt the Ottoman Majallah (Mecelle). ${ }^{27}$ Despite the existence of Murshid Al-Hayran as an Egyptian version of codified Shari'a law modeled after the Ottoman Majallah, which was originally intended to serve as an Egyptian civil code, Egypt's government implemented codes inspired by the Napoleonic code. Egypt's reliance on the

21. See RenÉ David \& John Brierley, Major Legal Systems IN THE WORLd TODAY 22 24 (3d ed. 1985) (The Romano-Germanic family is one of three main legal families besides the Socialist law family and the Common law family. This classification is based on the techniques of enunciation and the methods of reasoning in the interpretation of the rules rather than on the similarity of rules).

22. $I d$.

23. $I d$.

24. Id. See also BLACK's LAW DictionaRY 275 (9th ed. 2009) (defining codification as "the process of compiling, arranging, and systematizing the laws of a given jurisdiction, or of a discrete branch of the law, into an ordered code." The codification of statutes makes laws easily accessible for other jurisdictions seeking legal authorities).

25. EGYPT: A COUNTRY STUDY (Helen Chapin Metz ed., 1990), available at http://countrystudies.us/egypt/21.htm.

26. See EgYPT AND ITs Laws, XXIV-XXVII (Nathalie Bernard-Maugiron \& Baudouin Dupret eds., 2002).

27. The Ottoman Majalla, promulgated in 1876, is the first codified version of civil rule of Islamic Shari'a. Although Egypt was part of the Ottoman Empire, it did not incorporate the Majalla in its law. Rather, Egypt relied on the French Napoleonic code in forming its laws. Id. 
French codes was partially due to its anticipation of the British occupation; the codification of the French law also provided easy access to its authorities.

"Whatever may have been the foreign influence on drafting of Egyptian codes, their adoption, at the same time as the Mixed and National Courts were created, most fundamentally and lastingly established the very principle of a codified legality decided upon and amended by a legislator., ${ }^{28}$ After the abrogation of the Mixed Courts, a unified civil code prepared by AlSanhuri was put into force in $1949 ;{ }^{29}$ it still functions as the current Egyptian civil law. AlSanhuri is said to have attempted to Islamize the new code. ${ }^{30}$ This did not impede a subsequent hunt for legal authority from French laws by Egyptian legal professionals.

\section{Takeover Law Transplantation}

Western political influence has led Egypt to become a civil law country, and the corpus juris of the French law inevitably inspired the Egyptian codes. The French legal system continues to steer the legal development in Egypt today. The Egyptian takeover regulation is an example.

The Egyptian government regulated takeovers in 2007 in response to the growing number of takeovers over the last few years. ${ }^{31}$ Takeover regulations are supposedly part of the plan to integrate Egypt's capital market into the global market by developing its laws to conform to the latest international trends and complying with corporate governance standards. The advertised purpose of such regulation is to attract more investments to the Egyptian markets while observing the highest standards of corporate governance. As the Egyptian corporations are marked with high concentrations of ownership, takeover regulations were meant to encourage takeovers and also to protect the interests of minority shareholders. ${ }^{32}$

28. Id. at XXVI.

29. AlSanhuri is one of the most celebrated Arab jurists in the twentieth century. Espousing a comparative approach, he drafted many of the laws of the newly independent Arab States. In this sense, AlSanhuri is something of a vernacular Justinian in the Arab world. For more on AlSanhori's work, see Amr Shalakany, Sanhuri and the Historical Origins of Comparative Law in the Arab World (Or How Sometimes Losing Your Asalah Can Be Good For You), in RETHINKING THE MASTERS OF COMPARATIVE LAW 152, 152-65 (Annelise Riles ed., 2001).

30. AlSanhuri's work initially started as an Islamizing project of the Egyptian civil code, but he ended up reneging on this claim when Nasser came to power. See Amr Shalakany, Between Identity and Redistribution: Sanhuri, Genealogy and the Will to Islamise, 8 ISLAMIC L. \& SOC'Y 201 (2001).

31. See generally Shahira Abdel Shahid, Does Ownership Structure Affect Firm Value? Evidence from the Egyptian Stock Market 14 (Jan. 2003) (unpublished Working Paper), available at http://papers.ssm.com/sol3/papers.cfm?abstract_id=378580; see also Ahmad A. Alshorbagy, Orascom Telecom Versus France Telecom: A Case Study on Egyptian Takeover Law, 20 INFO. \& COMM. TECH. L. 157, 158 (2011).

32. ERCML, supra note 11, at art. 92 (outlining the purpose of the Egyptian takeover regulations as to, inter alia, establish full transparency in accordance to the laws and best 
To this end, Egypt has fashioned its takeover regulations based on the French model. This Article argues that the Egyptian takeover transplantation, however, has not been successful in part because it failed to honor the motivation behind its implementation. The failure of the takeover regulation transplantation is not attributed to the quality of the imported rules themselves, but rather to their incompatibility with the declared motives of the regulations. The imported rules discourage takeovers by increasing their costs and empowering incumbent controlling shareholders with the authority to resist prospective takeovers, which in turn affects minority shareholder rights.

\section{TAKEOVER REGULATIONS}

This Part of the Article outlines the main features of the European takeover model, which inspired the French takeover regulations. It examines the extent to which the French regulations embraced the European Union Takeover Directive. It then discusses the Egyptian takeover regulations and concludes with an examination of the reasons for the failure of transplanting the French takeover regulations to Egypt.

\section{A. The European Takeover Model}

Although there are different jurisdictions within Europe, the European Thirteenth Directive establishes the terms for a common structure of takeover laws. ${ }^{33}$ Contrary to the law of the United States, ${ }^{34}$ the European Directive restricts both the raider and the target company. There are two basic features of European takeover law: (1) the mandatory tender offer; and (2) the limitations imposed on the adoption of defensive measures. ${ }^{35}$

The mandatory tender offer rule requires a raider to tender an offer for all the outstanding shares of the target once a defined ownership threshold is triggered. ${ }^{36}$ The second feature appears in the limitations imposed on the adoption of any defensive measures by the target's board against a hostile bid. In addition to a board neutrality requirement, also referred to as the nonfrustration rule, ${ }^{37}$ limitations extend to any pre-bid measure interfering with shareholders' franchise or transferability of securities as required by the breakthrough rule. ${ }^{38}$ Although adopted by most of the European Union

international practices, to secure impartiality and equal opportunities between all shareholders, and to protect the interests of the target company and its activities).

33. Council Directive 2004/25, ๆ 26, 2004 O.J. (L 142) 12 (EC).

34. The laws of the United States allow buyers to acquire any number of shares while permitting the target corporation to resist the bid by any reasonable defensive measures. See generally CHRISTIN M. FORSTINGER, TAKEOVER LAW IN THE EU AND THE USA: A COMPARATIVE ANALYSIS (2002).

35. Council Directive 2004/25, arts. 9, 11 ๆ 3, 2004 O.J. (L 142) 12 (EC).

36. Id. art. 5.

37. See id. art. 9.

38. Id. art. 11. 
members, Article 12 of the Directive provides an opt-out provision for the members who do not wish to apply any of the previous provisions. ${ }^{39}$ The Directive also only creates an outline for takeover rules and leaves the member States to determine the details.

\section{B. The French Takeover Regulations}

Following the Thirteenth European Directive on Takeover Bids, the French government decided to amend its executive regulations transposing the guidelines of the European Directive. ${ }^{40}$ The amended regulations introduced the mandatory tender offer rule that requires the bidder to launch a mandatory offer - in line with Article 5 of the European Directive - to all the target's shareholders. ${ }^{41}$ The mandatory tender offer is triggered at the threshold of 30 percent ownership of the voting securities of a company. ${ }^{42}$ It also applies to holders of between 30 percent and 50 percent of the total number of equity securities or voting rights of a company and who increase such holding by at least 2 percent of the company's total equity securities or voting rights within a period of less than twelve consecutive months. ${ }^{43}$ The Autorité Des Marchés Financiers (Financial Market Authority - AMF) has discretionary power to waive the mandatory offer requirement in certain cases. ${ }^{44}$ The price of the mandatory offer must be at least equal to the highest price paid by the bidder, or any concert parties, during the twelve months before the event triggering the crossing of the threshold. ${ }^{45}$ However, the AMF may request or authorize a price modification if either a manifest change in the characteristics of the target company or the market for its securities has occurred during the twelve months preceding the contemplated offer, or in the absence of transactions by the

39. Id. art. 12.

40. Décision du 28 Septembre 2006 de règlement général de l'Autorité des Marchés Financiers [Decision of September 28, 2006 concerning the Adaptation of the General Regulations of the Autorité des Marches Financiers], JourNAL OFFICIEL DE LA RÉCPUUBLIQUE Française [J.O.] [Officlal GazeTte OF France], Sept. 28, 2006. The Act of 31 March 2006 transposed the legislative provisions of the European Directive into the French Commercial Code, but the AMF Regulation, published on 28 September 2006, finalized the transposition of the Directive into French law. See AutoritÉ DES MARChÉs FinANCIERS, AMF, 2006 ANNUAL REPORT: CHAPTER III- CORPORATE FINANCE AND THE QuALITY OF FinANCIAL Disclosure 1 (2006) available at http://www.amf-france.org/documents/general/7944_1.pdf [hereinafter AMF].

41. General Regulation of the Autorité des Marchés Financier, Book II - Issuers and Financial Disclosure (last amended Jan. 31, 2011), art. 234-2 [hereinafter Issuers and Financial Disclosure].

42. Id. The 30 percent has been reduced from one-third on February 2011. The one-third threshold still applies in limited cases. See also id. art. 234-11.

43. Id. art. 234-5.

44. Id. arts. 234-7, -9 .

45. AMF, supra note 40, at 8; See also Issuers and Financial Disclosure, supra note 41, art. 234-5. 
offeror in the securities of the target company over the same twelve-month period ${ }^{46}$ In such situations, the price would be determined based on accepted valuation criteria. ${ }^{47}$ The consideration offered to the target can be cash, securities, or a combination of both. ${ }^{48}$

The French takeover regulations have also opted into Article 9 of the European Directive regarding the non-frustration of a pending offer unless a shareholder meeting held after the filing of the bid approves the action of the board. ${ }^{49}$ Reciprocity applies in this regard. ${ }^{50}$ If the bidding company itself were not subject to equivalent restrictions, the target's board would be released from the restrictions of the non-frustration rule and would be able to employ defensive measures against a pending offer. ${ }^{51}$ While France adopted the nonfrustration (board passivity) rule of the European Directive, it opted out of the breakthrough rule stipulated by Article 11 of the Directive. ${ }^{52}$ Reciprocity does not apply to Article $11 .^{53}$ In fact, the French takeover regulations increase the array of defensive measures available for target companies. ${ }^{54}$ Shareholder warrants, similar to American poison pills, are the most significant example of the French defensive policy. ${ }^{55}$ The change in the squeeze-out methods and the introduction of the automatic squeeze-out procedure that allows a bidder to buyout minority shareholders is another important feature of the French takeover regulations. ${ }^{56}$

The French takeover regulations thus require a bidder to launch a mandatory tender offer for all the shares of the target company while providing the target several means to resist a hostile offer. ${ }^{57}$ The French regulations purportedly transposing the European Takeover Directive have violated the Directive's main goal to encourage free capital movement by facilitating takeovers. The French law has been widely criticized within the European

46. See AMF, supra note 40, at 9.

47. See Id.

48. Issuers and Financial Disclosure, supra note 41, art. 231-8.

49. Id.

50. Id. art. 233-33.

51. See Memorandum, Fried, Frank, Harris, Shriver \& Jacobson LLP, Reforms to French Regulation of Takeover Bids 1 (2006), available at http://friedfrank.com/siteFiles/ ffFiles/060929_reforms_to_french_regulation.pdf [hereinafter Fried Frank]; AMF, supra note 40 , at 7 .

52. Briefing, Freshfields Bruckhaus Deringer, The Takeover Directive: implementation in France 3 (2005), available at http://www.freshfields.com/publications/pdfs/2005/ FrenchTakeover.pdf [hereinafter Freshfields].

53. Id. at 1 .

54. Fried Frank, supra note 51 , at 3.

55. Id. at 5 .

56. Issuers and Financial Disclosure, supra note 41, at ch. VI.; See also Freshfields, supra note 52 , at 4.

57. See Briefing, Freshfields Bruckhaus Deringer, Important Changes to French Takeover Regulations 4-5 (Oct. 2006), available at http://www.freshfields.com/ publications/pdfs/2006/16513.pdf. 
Union for this result. ${ }^{58}$ The French Legislature was motivated to adopt antitakeover policies because of the French desire to protect national businesses and industries from being overtaken by foreigners. ${ }^{59}$

France's determination to resist takeovers is the key to understanding the inadequacy of its takeover rules for the Egyptian capital market; the same rule cannot serve opposite purposes unless properly adjusted. The French takeover rules, which discourage takeovers, will not encourage takeovers when transplanted to Egypt.

\section{The Egyptian Takeover Regulation}

In 2007, Egypt created its first comprehensive takeover regime by adding a new Chapter regulating takeovers ${ }^{60}$ in the executive regulations ${ }^{61}$ of the Capital Market Law. ${ }^{62}$ The Egyptian takeover scheme is modeled after the French scheme insofar that their rules are almost identical. ${ }^{63}$ The Egyptian regulations require bidders seeking control to extend mandatory tender offers and restrict target companies' boards from frustrating pending offers, but the Egyptian regulations do not impose a breakthrough rule to prohibit pre-bid defenses against hostile takeovers. ${ }^{64}$

The new regulations deal with the mandatory tender offer requirements in three articles. Under Article 353, the mandatory tender offer rule is triggered in two situations. The first situation applies to any bidder whose ownership of the company's securities or voting rights exceeds one-third of a corporation's stocks or voting rights. The second situation applies to holders of one-third but less than one-half of a corporation's securities or voting rights who increase

58. See Adam Cohen, EU Is Likely To Drop Its Fight With France on Takeover Law, WALL ST. J., May 25, 2006, at A8.

59. See Serf, French Takeover Law, ThE RoAD to EuRo SERfDom (Jan. 4, 2006, 11:48 AM), http://eu-serf.blogspot.com/2006/01/french-takeover-law.html (describing the French takeover law as a "poison pill to stop takeover in certain sectors," and that this policy is derived from economic ignorance).

60. Minister of Investment Decree No. 12 of 2007 (Amending Some Provisions of the Executive Regulations of the Capital Market Law No. 95 of 1992 issued by Decree of the Minister of Economics and Foreign Trade No. 135 of 1993), Al-Waqa' $i$ ' al-Misriyah, 4 Feb. 2007, vol. 26 pp. 2-30 (Egypt).

61. ERCML, supra note 11.

62. Law No. 95 of 1992 (Capital Market Law), Al-Jarida Al-Rasmiyya, 22 June 1992, vol. 25, art. 25 (Egypt).

63. This Article describes the Egyptian takeover regime as one that embraced the European takeover approach to a great extent. It is, however, more accurate to describe the Egyptian takeover regime as one that adopted the French model rather than one that adopted the European model, considering that the French model, unlike the European model, discourage takeovers. See Radwa S. Elsaman \& Ahmad A. Alshorbagy, Doing Business in Egypt After the January Revolution: Capital Market and Investment Laws, 11 Rich. J. GlOBAL L. \& Bus. 43, 46 (2011).

64. Law No. 95 of 1992 (Capital Market Law), Al-Jarida Al-Rasmiyya, 22 June 1992, vol. 25 , art. 8 (Egypt). 
their ownership stake by more than 2 percent within twelve consecutive months or if their ownership exceeds one-half of the corporation's securities or voting rights at any time. The same provisions apply to holders of more than 50 percent but less than 75 percent of the corporation's stocks or voting rights who increase their ownership by more than 2 percent within twelve consecutive months or whose ownership exceeds the 75 percent threshold at anytime. ${ }^{65}$ The price of the mandatory tender offer must be as high as the highest price paid by the acquiror, or any affiliated party in a previous tender offer during the twelve months preceding the tender offer in question. ${ }^{66}$ Consideration may be cash, securities, or a blend of both. However, when the consideration contains securities, target shareholders must have a cash alternative available if they choose to withdraw from the new corporation. ${ }^{67}$

The Egyptian regulations further impose a non-frustration rule on the board of the target corporation. The rule prohibits the board of the target corporation from undertaking any action or procedure that is considered a "significant detrimental event" starting from the date of publishing the decision approving the tender offer by the competent authority and extending until the conclusion of the tender offer. ${ }^{68}$ The regulations provide two examples of significant detrimental events. The first involves increasing the target capital or issuing new convertible bonds if such an increase would make the acquisition difficult or impossible. ${ }^{69}$ The second is broad and includes any actions that would significantly affect the target's assets or increase its obligations. ${ }^{70}$ Additionally, the target corporation cannot buy its own shares once the offer is published. ${ }^{71}$

Like the French takeover regulations, the Egyptian regulations are without a breakthrough rule that restricts the target from employing general prebid defensive measures. The omission of the breakthrough rule undermines the restriction of the board neutrality rule and empowers the controlling shareholder who would have absolute power to resist or accept an offer by duly adopting pre-bid defenses.

65. ERCML, supra note 11 , art. 353.

66. Id. art. 354/1 ("The price of the mandatory tender offer may not be less than the price paid by the offeror, or any person affiliated with him, in a previous tender offer during the last twelve month preceding the tender offer in question") (emphasis added).

67. Id. art. $328 / 3$.

68. Id. art. 343 . See also id. art. 326 (defining a significant detrimental event as "any expected event arising after launching the offer that would have a negative effect on the target company, its business or the share value") (emphasis added).

69. Id. art. 343/1.

70. Id. art. $343 / 2$.

71. Id. art. 351. 
D. The Incompatibility of the French Model with the Egyptian Legal

Environment

\section{Different Motives}

Takeover regulations are part of the economic policy of any state. The purpose of takeover regulations depends on the economic policy of each jurisdiction. Despite being a member state in the European Union, France has always been choleric about the integrity of its national investments. The French apply hostile policies to foreign investments as a result of constant concern over its industries falling into the hands of rivals. These same policies continue to apply in the regulation of takeovers.

This is best understood in light of the long history of the Thirteenth European Directive. The struggle between the European states over the rules of the European Directive on Takeovers resulted in several failed attempts to reach an agreement on reform proposals. ${ }^{72}$ As a result, the rules of the Directive have been the subject of great compromises to gain the hard-won agreement of the member states of the European Union. The outcome of such compromises is a great margin of flexibility, which allows each member state to opt out or to apply reciprocity requirements to some substantial rules of the Directive. ${ }^{73}$

This flexibility led to a great deal of inconsistency in the transposed takeover rules of the member states. As the European Directive established the main guidelines for allowing member states to tailor their takeover laws according to their policies, the effect of transposing the Directive's rules is not the same in the different states. Indeed, the French takeover regulations negate the purpose of having a unified set of takeover rules, which is to secure free and easy transfer of capital across borders.

This makes it important to consider the individual state's policy as well as other factors that may determine the effect of the adopted rules of takeovers in a

72. See generally Philippe Lambrecht, The 13th Directive on Takeover Bids - Formation and Principles, in Capital MARKets IN THE AGE OF THE Euro 441 (G. Ferrarini et al. eds., 2002); ANDREA ANGElillis \& CHIARA MOSCA, THE THIRTEENTH DireCTIVE ON TAKEOVER BIDS: A FIRST ANALYSIS IN THE LIGHT OF THE INITIAL EXPERIENCES AFTER TRANSPOSITION BY MEMBER States AND tHe Position EXPRESSED IN THE European CoMmission DOCUMENT 4 (2007), available at $\mathrm{http}: / / \mathrm{www}$. side-isle.it/ocs/viewpaper.php?id=57\&cf=1; John Armour \& David Skeel, Jr., Who Writes the Rules for Hostile Takeovers, and Why? The Peculiar Divergence of U.S. and U.K. Takeover Regulation, 95 GEO. L.J. 1727, 1757-63 (2007) (discussing the historical development of takeover rules in the U.K. before their implementation in the Thirteenth European Directive); Marco Ventoruzzo, Takeover Regulation as a Wolf in Sheep's Clothing: Taking U.K. Rules to Continental Europe, 11 U. PA. J. BUS. \& EMP. L. 135, 145 (2008) (highlighting the adoption of the U.K. approach in some European countries prior to the Thirteenth Directive).

73. See, e.g., Council Directive 2004/25, \ 6, 8, art. 12, 2004 O.J. (L 142) 12 (EC). 
certain state. These factors include the corporate ownership structure, ${ }^{74}$ the strength of the financial markets, as well as other factors related to the legal and institutional infrastructure of each state. Proper attention was not paid to these factors upon the transplantation to Egypt of the French model of takeovers, which has diverged from the European model's purpose. As a developing country, Egypt strives to attract more investments by committing to reform its economic laws and developing its financial markets. ${ }^{75}$ Transplanting an antiinvestment takeover regime contradicts the Egyptian general policy of economic reform. This, combined with the lack of a developed infrastructure, contributes to the failure of the takeover rules transplanted to Egypt. The transplanted rules defeat some of the purposes stipulated in the very same regulations, such as guaranteeing equality between the target's shareholders and pursuing the interests of the company rather than private interests. ${ }^{76}$

\section{Institutional Incompetence}

Essential to the success of any legal system is a functional institutional infrastructure. This entails executive institutions that implement the rules of the law. In addition, an effective court system that provides ex-post judicial supervision over the work of the executive institutions is an important element in the institutional infrastructure.

In 2009, the Egyptian legislature established the Egyptian Financial Supervisory Authority (EFSA) to replace, inter alia, the Capital Market Authority (CMA) ${ }^{77}$ The EFSA thus became the main regulator and supervisor of all non-banking financial markets. ${ }^{78}$ Gathering the authorities of all non-

74. See, e.g., Ventoruzzo, supra note 72 , at 134,141 (describing the application of the United Kingdom rules to Continental Europe as "a wolf in sheep's clothing," because it serves the opposite of its purpose in highly concentrated ownership structures by allowing the incumbent controller to entrench itself through increasing the costs of takeovers, and hence blocking efficient takeovers instead of protecting the minority shareholders).

75. See generally Shahira Abdel Shahid, Corporate Governance Is Becoming a Global Pursuit: What Can Be Done in Egypt? 42 (Cairo \& Alexandria Stock Exch., Working Paper No. 1, 2001), available at http://papers.ssrn.com/abstract=286875; Shahira Abdel Shahid, Institutional Reform: Privatization of the Egyptian Exchange (unpublished Working Paper, 2004), available at $\mathrm{http}: / / \mathrm{ssrn} . \mathrm{com} / \mathrm{abstract}=593365$ (discussing the steps taken by the Egyptian government to revive the Egyptian capital markets and attract more investors to it).

76. ERCML, supra note 11, art. 327.

77. Law No. 10 of 2009 (Regulating Non-Banking Financial Markets and Instruments), $A l$ Jarida Al-Rasmiyya, 1 Mar. 2009, vol. 9, art. 3 (Egypt).

78. Id. ("The Authority shall replace the Egyptian Insurance Supervisory Authority, the Capital Market Authority, and the Mortgage Finance Authority in enforcing the provisions of the Insurance Supervision and Control Law no. 10 of 1981, the Capital Market Law no. 95 of 1992, the Depository and Central Registry Law no. 93 of 2000, the Mortgage Finance Law no. 148 of 2001, as well as any other related laws and decrees that are part of the mandates of the above authorities. The Authority shall be considered the competent administrative body entitled to enforce the financial leasing provisions promulgated by Law no. 95 of 1995.") 
banking financial supervisors, the EFSA has wide authority aimed at harmonizing the regulation of the non-banking financial market. ${ }^{79}$ Despite its wider authority and broader objectives, the EFSA resembles the former CMA in that it is a public authority reporting and attached to the Ministry of Investment as stipulated by the law. ${ }^{80}$

Being affiliated with the Minister of Investment undermines the EFSA's independence. The EFSA must obtain the Minister of Investment's approval for some decisions, despite having the power to decide many issue presented to it. $^{81}$ For example, the EFSA is the authority charged with inspecting corporations upon the request of their shareholders or if the EFSA suspects misconduct in any corporation. Despite this authority, the request is first submitted to the competent Minister who then forms an inspection committee to investigate the request. ${ }^{82}$ The same applies to the case of evaluating in-kind shares during the formation of a new corporation. Upon the EFSA's Chairman referral, the Minister forms an evaluation committee. "'This limits the EFSA's role to ... suggesting a course of action rather than actually" deciding such matters. ${ }^{84}$

Equally important, the political and governmental influence on the EFSA's board also threatens its independence. Before the January revolution in Egypt, a single party dominated all aspects of political life. ${ }^{85}$ The EFSA's board consists of nine members: a chairman, two vice-chairmen, one deputy governor of the Central Bank of Egypt, and five experienced members. ${ }^{86}$ The Egyptian Prime Minister, upon the advice of the Minister of Investment, issues a decree appointing members to the board for a four year, non-staggered renewable term and determines their compensation. ${ }^{87}$ This method of appointing members to the board jeopardizes its independence. Board member may be appointed for reasons of partisan affiliation as opposed to competence. Coupled with the four-

79. Id. art. 4(a) ("The Authority shall maintain the safety, stability, organization and development of non-banking financial markets, and balance the market dealers rights. In addition, the Authority shall provide means and systems, and issue rules and regulations to guarantee the efficiency of non-banking financial markets and ensure transparency of activities undertaken").

80. Id. art. 1(a); Presidential Decree 192/2009 (Establishing the EFSA Charter), Al-Jarida Al-Rasmiyya, 14 June 2009, vol. 24, art. 1 (Egypt).

81. Elsaman \& Alshorbagy, supra note 63 , at 56.

82. Law No. 159 of 1981 (Companies Law), Al-Jarida Al-Rasmiyya, 1 Oct. 1981, vol. 40, art. 158 (Egypt).

83. Elsaman \& Alshorbagy, supra note 63 , at 56.

84. Id.

85. Id. at $n .99$. (discussing "[t]he National Democratic Party, controlled by some influential businessmen," completely monopolized Egyptian political life and economic policy until the January Revolution on January 25, 2011.)

86. Law No. 10 of 2009 (Regulating Non-Banking Financial Markets and Instruments), AlJarida Al-Rasmiyya, 1 Mar. 2009, vol. 9. art. 5(a) (Egypt).

87. Id. art. 5(c). 
year renewable term, this may also "prejudice the judgment of board members who want to keep their positions.

Lessons may be learned from the organization of the French AMF. Just like the EFSA, the French AMF is a public, independent authority, established in 2003 by the merger of three authorities. ${ }^{89}$ AMF's board consists of "sixteen members, all of whom are nominated by different public authorities," including: the President of the Republic, the President of the Senate, two different judicial authorities, the Minister of Finance, and other authorities. ${ }^{90}$ Not only does this dispersion in nominating board members guarantee their impartiality, but it also allows each authority to choose the most competent candidate. The larger number of board members permits better representation of the various constituencies involved in the industry, and the board benefits from the experience of members with different backgrounds. The AMF's board is staggered with officers partially replaced every thirty months; ${ }^{91}$ this maintains the stability of boards and eases the transfer of power from one board to another.

The EFSA's board structure is better than some of its counterparts in other emerging Arab markets. ${ }^{92}$ For instance, the newly established Capital Market Authority of Kuwait (KCMA) and the Saudi Arabian Capital Market Authority (SCMA) adopted the structure of the American Securities and Exchange Commission (SEC) but with a twist. As an independent federal agency, the SEC has a much larger managerial body and a significantly different structure than the AMF, the EFSA, the KCMA, or SCMA. ${ }^{93}$ The SEC's board has five bipartisan Commissioners who are presidentially appointed with the advice and consent of the United States Senate for a term of five years. ${ }^{94}$ The President also designates one of the Commissioners as a Chairman. To guarantee that the Commission remains non-partisan, no more

88. Elsaman \& Alshorbagy, supra note 63, at 56.

89. These authorities were as follows: the Commission des opérations de Bourse (COB), the Conseil des marches financiers (CMF), and the Conseil de discipline de la gestion financière (CDGF). See Autorité Des MARChÉs FINANCIERS (AMF), IN PROfILE 2 (2009), available at http://www.amf-france.org/documents/general/9013_1.pdf.

90. The AMF Board, Autorité Des MARChÉs FINANCIERS (AMF), http://www.amffrance.org/affiche page.asp?urldoc $=$ college.htm\&lang $=$ en\&Id_Tab=0 (last visited Mar. 30, 2012).

91. Id.

92. The board of the Central Bank of Bahrain, which is the Bahraini market regulator, is closely structured to the EFSA's board. It consists of 7 members, all of whom are appointed by a Royal Decree for a renewable term of four years. See Central Bank of Bahrain and Financial Institutions Law, art. 5 (2006) (Kingdom of Bahrain).

93. In addition to its five Commissioners, the SEC consists of four Divisions and nineteen Offices, encompassing over 3000 staff members. See U.S. SeC. ExCH. COMM'N, PERFORMANCE AND ACCOUNTABILITY REPORT 7 (2006) [hereinafter SEC], available at http://www.sec.gov/ about/secpar/secpar2006.pdf\#sec1.

94. Id. 
than three Commissioners may be appointed from the same political party. ${ }^{95}$ Commissioners' terms last for five years and are staggered so that one commissioner is replaced every year. ${ }^{96}$

In Kuwait, the KCMA likewise has a board of five commissioners appointed by a decree upon the recommendation of the competent Minister for a five-year term, which is renewable once. ${ }^{97}$ The same applies to the SCMA except that the commissioners are called board members. ${ }^{98}$ While the SEC's Commission is independent, staggered and supported by a huge managerial body, the KCMA and SCMA lack these characteristics.

Independence aside, the composition of the EFSA's board may be enhanced to improve its performance. Nine board members may be too few considering the wide authority of the EFSA. Although experience is a prerequisite in all board members, ${ }^{99}$ the board's formation does not require or guarantee the representation of the various stakeholders affected by its decisions. For example, it was suggested that a justice from the Court of Cassation, who would be changed periodically, be appointed to the board of the former CMA, so that judges become engaged in what happens in practice. ${ }^{100}$

The structure of the EFSA also includes a body of employees drawn from staff members of the merged authorities. ${ }^{101}$ Some of the members are vested with the powers of judicial officers that give them the authority to verify crimes falling under the EFSA's supervision. ${ }^{102}$ Due to the complexity of laws and regulations concerning the capital market and its nascence, EFSA's staff may still lack the experience needed to become fully competent. ${ }^{103}$

95. Id. See also SEC Organization and Management, U.S. SEC. ExCH. COMM'N, http://www.sec.gov/about/offices/oia/secorg.htm (last visited Mar. 30, 2012).

96. Id.

97. Board of Commissioners of KCMA Decree No. 4-2 of 2011 (Regarding the Issuance of the Executive Regulations of Capital Market Law No. 7 of 2010), 3 Mar. 2011, art. 6, 10 (Kuwait).

98. Capital Market Law, Chapter 2: Capital Market Authority, art. 7 (Saudi Arabia), available at http://www.cma.org.sa/En/AboutCMA/CMALaw/Pages/Ch2Article7.aspx.

99. Presidential Decree 192 of 2009 (Establishing the EFSA Charter), Al-Jarida AlRasmiyya, 14 June 2009, vol. 24, art. 7-8 (Egypt).

100. Mohamed Tanwir Alrafie, Door Almya'a Al'Ama Lesook Almal Fi HMayt AKLyt almshahemin Fi ShrKat almosahama [Role of the Capital Market Authority IN

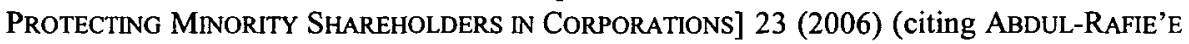
Mousa, AlHya'a Al'Ama Lesook Almal [CAPITAl Market Authority] 75 (1988)). Despite the irrelevance of this argument, engaging judges as legal experts in decision-making acts as an ex-ante screen of such decisions, decreases the likelihood of breaching the law and bringing a case to the court, and thus increases the competency and efficiency of the board.

101. Law No. 10 of 2009 (Regulating Non-Banking Financial Markets and Instruments), $A l$ Jarida Al-Rasmiyya, 1 Mar. 2009, vol. 9, art. 9 (Egypt).

102. Id. art. 15.

103. On July 8, 2010, a group of investors reported EFSA's Chairman along with former EGX Chairman to the Egyptian Public Prosecutor (General Attomey), accusing them of destroying the national economy and charging them with the deterioration of EGX. A week 
Comparing the structures of the EFSA, the AMF, and the SEC highlights the importance of an independent authority. Both the AMF and the SEC employ different strategies to ensure and sustain this independence. The AMF does so by dispersing the appointing authority of the members. The SEC does so by assuring that the commission remains non-partisan. Additionally, the diverse candidacy of board members is an advantage because it allows for better representation and more experiences. Having a staggered board is also useful for easing the transfer of power without undermining the stability of the board. Absent such changes that guarantee its independence and efficiency, the EFSA's competence as the main financial market regulator in Egypt remains in question.

In an attempt to enhance judicial supervision over commercial disputes, Egypt created specialized courts called the Economic Courts (AlMhakim Allqtisadiya). ${ }^{104}$ Establishing specialized courts is a growing trend in Egypt, as well as in several other developing countries. The aim of these specialized courts is to improve the decision making process by allowing expert justices to handle specific cases. Specialized courts should be distinguished from commercial circuits within civil courts. Because of the large number of cases in civil courts, each court is divided into several specialized circuits that deal with certain types of cases such as civil, criminal, or commercial. ${ }^{105}$ This division is merely an internal administrative division within the same court and has nothing to do with the general jurisdiction of courts. Thus, a different circuit within the same court may not deny hearing to a specific case based on its incompetence over such a case if it falls within the jurisdiction of the court. ${ }^{106}$

Established in 2008, economic courts are supposed to have jurisdiction over commercial disputes exceeding a certain value including commercial criminal cases. ${ }^{107}$ Undoubtedly, the stated jurisdiction of economic courts was expected to extend to corporate disputes and disputes involving capital market

later, the latter was removed from his position after four years in service. See Ahmad Chalabi \& Abdul Rahman Shalabi, Prosecutor Begins to Investigate the Reports of Wasting Public Money in the Stock Market, ALMASRY-ALYOUM (July 13, 2010), http://www.almasryalyoum.com/article2.aspx?ArticleID=262362.

104. Law No. 120 of 2008 (Law on the Establishment of Economic Courts), Al-Jarida AlRasmiyyah, 22 May 2008, vol. 21 (Egypt).

105. Nathan Brown, Arab Judicial Structures: A Study Presented to the United Nations Development Program, UNITED NATIONS, http://www.undp-pogar.org/publications/judiciary/ nbrown/egypt.html.

106. TAlaAT Dowidar, Almahakm AliQtasdia [The ECONOMiC COURTS] 10 (2009); Law No. 120 of 2008 (Law on the Establishment of Economic Courts), Al-Jarida Al-Rasmiyyah, 22 May 2008, vol. 21 (Egypt) (The Explanatory Note, The Preparatory Works Thereof \& The Complementary Statutes Thereto, Book 6: The Most Important Advantages and Criticism of the Economic Courts Law).

107. Law No. 120 of 2008 (Law on the Establishment of Economic Courts), Al-Jarida AlRasmiyyah, 22 May 2008, vol. 2, art. 4-6 (Egypt). 
laws if they exceed the value threshold of the dispute. ${ }^{108}$ Nevertheless, the first takeover dispute following the establishment of the Economic court triggered a jurisdictional conflict between the Economic courts and the Administrative courts known as the "Conseil d'Etat" or the "Council of the State."

The Administrative court's jurisdiction extends to all disputes involving the State as a sovereign authority. In the first takeover dispute, Administrative Courts claimed jurisdiction because the dispute resulted from appealing the EFSA's decision approving a mandatory tender offer. Economic courts, however, claimed jurisdiction based on the subject matter of the dispute which involved a takeover transaction valued at over 5 million EGP. Administrative courts won jurisdiction over the dispute. This undermines the role of the economic courts and poses questions concerning the reason for its establishment and the degree of its efficiency.

The jurisdictional conflict over that takeover dispute highlights the ineptitude of the Egyptian judicial system in handling capital market cases. The problems relate not only to the quality of judges, the clarity of the laws, and the methods of interpreting and implementing such laws, but also the preliminary matter of court jurisdiction. A legislative intervention is needed to solve this issue.

\section{Weak Legal Infrastructure}

\section{a. Validity Doubts}

An Egyptian legislative trend has been to rely heavily upon executive regulations rather than statutes when regulating capital markets. Capital market law provides general "guidelines to regulate the different areas of securities law and leave[s] the details" to executive regulations. ${ }^{109}$ The flexibility of capital market law explains the large number of amendments to the executive regulations of the capital market law over the last decade. ${ }^{110}$ This provides the government a quick and easy method to cope with market developments and to regulate a variety of activities by adding a few articles to the executive regulations without having to amend the statute itself via the parliament. ${ }^{11}$

108. Id. art.6 ("[W]ithout exception, appellate circuits of the court shall have original jurisdiction over the disputes previously mentioned in the article of value exceeding five millions EGP.").

109. Elsaman \& Alshorbagy, supra note 63, at 54.

110. See id. at $\mathrm{n} .83$ (The executive regulations have been amended over ten times in less than five years. These include amendments by Ministerial Decrees Nos. 46/2004, 192/2005, 1/2006, 14/2006, 139/2006, 140/2006, 141/2006,301/2006, 314/2006, 84/2007, 12/2007, 126/2008 and others.); ALRAFIE, supra note 100, at 23-25 (discussing the flexibility of the Capital Market Law as one of its distinctive features).

111. Elsaman \& Alshorbagy, supra note 63, at 55 ("For instance, several activities related to securities were added, such as regulating the buying securities with margin, borrowing securities 
Despite the benefits of this approach, regulating through the executive regulations may impede important procedural and objective safeguards which may affect the quality of the regulations. Procedurally, as decrees issued by the competent Minister, executive regulations do not go through the law-making process that includes professional drafting, specialized committee review and revision, and parliamentary debate. ${ }^{112}$ Objectively, any statute enacted by the Parliament comes with an explanatory memorandum that provides guidance for understanding the provisions of the statute and captures the intended interpretation of such provisions. ${ }^{113}$ All these procedures result in a better drafted, clearer statute. As will be discussed below, the absence of this lawmaking process has greatly influenced the quality of the Egyptian takeover regulations.

More significantly, as the executive regulations are necessary for the implementation of a certain statute, they are only valid insofar as they do not violate or add to the statute. Thus, the Executive Authority may issue executive regulations as necessary for the application of the statues without amending the statute or disabling or exempting its application. ${ }^{114}$ Conferring such legislative power upon the Executive Authority does not mean the Legislative Authority waives its power to legislate. Rather, the Executive Authority uses its power to promulgate the detailed rules necessary for the application of a statute without adding, amending, or disabling any of the statute's provisions. ${ }^{115}$ Consequently, an executive regulation's scope is strictly limited to the piece of legislation it serves to implement. Therefore, an executive regulation cannot go beyond the four corners of the legislation. ${ }^{116}$ Otherwise, the executive regulation is invalid.

Takeovers are not regulated in the capital market law. ${ }^{17}$ Article 8 of the capital market law only imposes some disclosure requirements upon acquiring a certain percentage of the voting securities of a corporation. ${ }^{118}$ Other than this instance, there is no mention of takeovers in the entire statute. The executive regulations have added to the law by requiring a mandatory tender offer, restricting the board of the target, and imposing several obligations on the bidder. This raises strong doubts concerning the validity of such a regulation.

The French transposition of the European takeover rules took place in two steps. First, the statute was amended to transpose the principles of the Directive (Act No. 2006-387 of 31 March 2006 amending the French Monetary and Financial Code), and then the details were put into the secondary statute of

for sale, and securitization. Executive regulations have also set forth rules banning the manipulation of prices and insider trading in its Eleventh Part.").

112. Id. at $54 \mathrm{n} .84$.

113. Id

114. Id. at $54-55$.

115. Case no. 528//1975/Court of Cassation, (Egypt).

116. Elsaman \& Alshorbagy, supra note 63, at 55.

117. Id. at 64 .

118. Law No. 95 of 1992 (Capital Market Law), Al-Jarida Al-Rasmiyya, 22 June 1992, vol. 25, art. 8 (Egypt). 
the AMF regulations. ${ }^{119}$ For example, Article L $433-3$ of the French Monetary and Financial Code was amended to reflect the new rules for determining the price of the mandatory tender offer. ${ }^{120}$ The AMF regulations then determined how to apply such rules and the cases where it may authorize a change in that price. $^{121}$

The new Kuwaiti law also provides a good example. The Kuwaiti Capital Market Law No. 7 of 2010 sets forth guidelines for takeover transaction in five Articles. ${ }^{122}$ These guidelines define, inter alia, important disclosure thresholds and levels triggering mandatory bid requirements. ${ }^{123}$ The executive regulations of this law then implement these guidelines by adding the necessary details for its application. ${ }^{124}$

By regulating takeovers through executive regulations, the Egyptian government has put itself in the position of the legislator to combine the policymaking function and policy-implementing function. The lack of statutory basis for the Egyptian takeover regulations violates the principle of separation of powers and is indicative of a lack of a proper legal infrastructure. The Egyptian takeover regulations are tainted with invalidity due to the weak legal infrastructure they rest upon. It is essential that the Egyptian legislature amend the capital market law to reverse this issue and establish some basis for the takeover regulations.

\section{b. Regulatory Shortcomings}

The lack of proper legal infrastructure and clear policy upon which the Egyptian takeover law was developed has had a negative impact on the quality of its provisions. This impact is reflected in the blind copying of the French law even though the copied rule may negate the premeditated purpose of the regulations. It is also revealed in the poor drafting of the articles of the regulations, as well as in the vagueness of some provisions of the regulations.

The executive regulations of the capital market law introduced the mandatory tender offer requirement to the Egyptian capital market for the first time. This is considered an addition to the capital market law by its executive regulations which is enough of a violation to the hierarchy of the law to render this provision invalid. The mandatory tender offer rule is a clear example of the

119. See Issuers and Financial Disclosure, supra note 41.

120. Id. art. 231-13.

121. Id. art. 234-6.

122. Impact of the New Kuwait Capital Markets Law and Regulations, LINKLATERS(May 12, 2011), http://www.linklaters.com/Publications/GCC/May/Pages/Impact_New_Kuwait_Capital_ Markets_Law_And_Regulations.aspx.

123. $\bar{I} d$.

124. Kuwait Capital Market Authority Successfully Ends First Phase of Transitional Period, KuwAIT NEwS AGENCY (Sept. 19, 2011), available at http://www.kuna.net.kw/ ArticleDetails.aspx $? \mathrm{id}=2191266$ \&language $=\mathrm{en}$. 
lack of legislative guidelines and law-making due process.

The first issue with the Egyptian mandatory tender offer rule is its triggering threshold. The Egyptian regulations set a general threshold to trigger the mandatory tender offer rule at acquiring one-third of the voting securities of a corporation. This trigger is the presumed level of ownership that allows a shareholder to control a corporation. If the threshold is set at too high a percentage of ownership, an acquiror can obtain de facto control over a corporation without having to launch a mandatory bid, which undermines the purpose of the rule. The one-third Egyptian threshold was derived from the French regulations. France, however, has now lowered this threshold to 30 percent. ${ }^{125}$ Bahrain and Kuwait takeover regulations set the mandatory bid thresholds at 30 percent, too, while Saudi Arabia has a higher threshold of 50 percent. $^{126}$

Although Egyptian corporations have a significantly higher concentration in ownership, ${ }^{127}$ which undermines the problem of de facto control over Egyptian corporations, it is unclear how the regulations determine the one-third threshold. It is most likely the result of copying a French regulation that was later amended to lower the threshold to 30 percent; an indication of the blind copying of the rules that will be affirmed with other incidents below.

The price of the mandatory tender offer represents one of the major problems in the Egyptian takeover regulations. Article 354 of the regulations reads, "[t]he price of the mandatory tender offer shall not be less than the highest price paid by the offeror, or any concert party, in a previous tender offer during the twelve months preceding the submission of the offer in question."128 There are two issues with this provision: one regarding the twelve-month period of calculating the price; and two relates to the method of determining it.

The Egyptian regulations also followed the French regulations in requiring the price to be not less than the highest price paid by the offeror in the twelve months prior to the contemplated offer. ${ }^{129}$ However, unlike the French regulations, the Egyptian takeover regulations did not adopt a price adjustment mechanism that allows the EFSA to adjust the price in certain cases where the price has been significantly changed. ${ }^{130}$

In the world of securities markets, twelve months is a very long time in which the value of securities may drastically change, whereas a very short

125. Issuers and Financial Disclosure, supra note 41, art. 234-6.

126. See Bahraini Takeovers, Merger, and Acquisitions Module, Central Bank of Bahrain, vol. 6, art. 3.1.1 (Bahr.); Board of Commissioners of KCMA (Law on the Issuance of the Executive Regulations of Capital Market Law No. 7 of 2010), 3 Mar. 2011, art. 271 (Kuwait); Royal Decree No. M/30 (Merger and Acquisition Regulation, Capital Market Authority), Board of Capital Market Authority 1-50-2007, Mar. 10, 2007, art. 12(a) (Saudi Arabia).

127. Shahid, supra note 31 , at 10.

128. ERCML, supra note 11 , art. $354 / 1$ (emphasis added).

129. See supra Part III.C.

130. Issuers and Financial Disclosure, supra note 41 , art. 234-6. 
period of time is also unfavorable as securities' value may be subject to the effect of speculation bubbles. Arab takeover regulations provide some insights. While the Saudi regulations adopt a twelve-month interval with a possibility of modifying such price upon the authorization of the SCMA, ${ }^{131}$ the Bahraini takeover module adopts a three-month interval, ${ }^{132}$ and Kuwaiti rules adopt a six-month interval. ${ }^{133}$ In determining the price of the offer, longer intervals of twelve months such as in France and Egypt are unfavorable compared to shorter intervals such as in Bahrain. ${ }^{134}$ In cases where a twelve-month interval is applied, a price adjustment mechanism is necessary to guarantee reaching a fair value.

The real concern over the Egyptian provision of the mandatory tender offer price is in its method of determining such price. The provision requires the price to be as high as the highest price paid by the offeror in a previous tender offer over the twelve months prior to the commencement of the tender offer at hand. ${ }^{135}$ It is unclear what would happen if the tender offer in question were the first offer from its offeror. The French provision, the assumed source of the Egyptian provision, requires the price of the mandatory bid to be "at least equivalent to the highest price paid by the offeror ... in the twelve-month period preceding the event that gave rise to the obligation to file a proposed offer." 36

Looking at the other Arab takeover regulations discussed in this Article, none have language similar to the Egyptian provision. The Saudi law requires the price of the offer to be "not less than the highest price paid by the offeror or any person acting in concert ... during the offer period and within twelve months prior to its commencement." 137 The Bahraini Takeovers, Merger, and Acquisition Module provision reads, "highest price paid by the offeror . . .

131. Royal Decree No. M/30 (Merger and Acquisition Regulation, Capital Market Authority), Board of Capital Market Authority 1-50-2007, Mar. 10, 2007, art. 12(d)(1)-(3) (Saudi Arabia).

132. Bahraini Takeovers, Merger, and Acquisitions Module, Central Bank of Bahrain, vol.6, art. 3.1.10 (Bahr.).

133. Board of Commissioners of KCMA (Law on the Issuance of the Executive Regulations of Capital Market Law No. 7 of 2010), 3 Mar. 2011, art. 274 (Kuwait).

134. Marco Ventoruzzo, Europe's Thirteenth Directive and U.S. Takeover Regulations: Regulatory Means and Political and Economic Ends, 41 TEX. INT'L L.J. 171, 198-99 (2006) (mentioning that Germany also adopts a shorter interval of three months).

135. ERCML, supra note 11, art. 326 (defining the tender offer as "the offer presented to the owners of securities subject to the offer whether the consideration was cash, securities, or mixed, and whether the offer was optional or mandatory.") (emphasis added).

136. Decision (Arrêté) of September 28, 2006 concerning the adaptation of the General Regulations of the Autorité des Marché Fianciers (AMF) Act no. 2006-387 of March 31, 2006 concerning public acquisition of offers. art. 234-6 (Fr.).

137. Royal Decree No. M/30 (Merger and Acquisition Regulation, Capital Market Authority), Board of Capital Market Authority 1-50-2007, Mar. 10, 2007, art. 12(d) (Saudi Arabia). 
during the offer period and within three months prior to its commencement."138 Likewise, the Kuwaiti regulations stipulate that the price shall be equal to the "average price of shares in the six months prior to the commencement of the offer. The Exchange shall determine such a price."139

None of the previous provisions on their diversion use similar language to the Egyptian provision. It is highly unlikely that the Egyptian provision is intended to mean "previous tender offer;" rather, from reading the other provisions, the suggested meaning is "the highest price paid in a previous transaction." The latter interpretation, although inconsistent with the express stipulation of the article, is the most similar to counterpart provisions.

Unlike the four compared takeover regulations, the Egyptian takeover regulations apply a twelve-month interval to calculate the price without having any price adjustment mechanism. Furthermore, the Egyptian article requires the price to be not less than the price paid in a previous tender offer omitting the normal (and more likely) case where the offer is the first by its bidder. Undoubtedly, this article is poorly drafted, which highlights another consequence of regulating takeovers through executive regulations and ignoring the law-making process. ${ }^{90}$

France has opted out of Article 11 of the European Directive regarding the breakthrough rule, which restricts the target from applying general pre-bid defensive tactics against prospective takeovers. ${ }^{141}$ Following in the French footsteps, the Egyptian takeover regulations came without a breakthrough rule. As noted earlier, the motives behind the French and the Egyptian regulations are different. ${ }^{142}$ France wants to protect its industries against the threat of being raided by international investors; whereas Egypt wants to attract more investments to its markets. ${ }^{143}$

This is reflected more clearly in the organization of the non-frustration rule in both the French and the Egyptian jurisdictions. While both restrict the board of the target corporation from frustrating an outstanding offer, the French

138. Bahraini Takeovers, Merger, and Acquisitions Module, Central Bank of Bahrain, vol.6, art. 3.1.10 (Bahr.).

139. Board of Commissioners of KCMA (Law on the Issuance of the Executive Regulations of Capital Market Law No. 7 of 2010), 3 Mar. 2011, art. 274 (Kuwait).

140. Indeed, statutes can be badly drafted too. However, the law-making process provides minimum guarantees for drafting better statutes.

141. See supra Part III.C.

142. See supra Part III.D.

143. It is surprising that all three Arab jurisdictions subject to comparison are without a breakthrough rule considering they are emerging markets that need to encourage investments, whereas they all impose non-frustration rules. See Royal Decree No. M/30 (Merger and Acquisition Regulation, Capital Market Authority), Board of Capital Market Authority 1-502007, Mar. 10, 2007, art. 24 (Saudi Arabia); Bahraini Takeovers, Merger, and Acquisitions Module, Central Bank of Bahrain, vol.6, art. 2.4 (Bahr.); Board of Commissioners of KCMA (Law on the Issuance of the Executive Regulations of Capital Market Law No. 7 of 2010), 3 Mar. 2011, art. 281 (Kuwait). 
use of antitakeover measures is more developed than in the Egyptian law, which hardly mentions defensive tactics. ${ }^{144}$ In fact, the Egyptian omission of the breakthrough rule allows a great deal of latitude to the board of target companies, dominated by controlling shareholders, to resist takeover. This not only undermines the importance of the non-frustration rule, but it also makes it extremely hard for a hostile takeover to succeed, especially when coupled with the mandatory tender offer requirement that raises the price of the deal. This difficulty in executing a successful takeover reduces the market for corporate control and the protection it provides for shareholders.

Blind copying of the French rules offers one theory to explain the unfavorable outcome of the Egyptian takeover regulations. Another theory may be attributed to the hegemony of some powerful businessmen over the Egyptian government, a situation not uncommon in Egypt during the last decade. These businessmen, who had private interests in controlling the securities market, may have tailored the law to serve their interests at the expense of public policy.

As a matter of corporate law, Egyptian corporations are marked with a high concentration of ownership, which makes the protection of minority shareholder rights an important issue. The Egyptian takeover regulations have addressed this issue and made protecting minority shareholders one of the regulations' main objectives. ${ }^{145}$ The regulations have a sub-section entitled "Protecting Minority Shareholder Rights Through Tender Offers". 146

Article 375 of the regulations gives the EFSA discretionary power to force the new controlling shareholder to tender an offer to buy the shares of minority shareholders upon the success of his tender offer in two cases. First, a holder of at least 3 percent of the corporation's capital may request from the EFSA, within twelve months of the acquisition of at least 90 percent of the corporation's capital or voting rights by the raider, that the controlling shareholder extend a tender offer to buy the minority's shares. The EFSA then decides upon such a request in light of prevailing market conditions and available information. If the request is approved, the EFSA requires the controlling shareholder to extend a tender offer within a prescribed period. Second, the EFSA may oblige the controlling shareholder who intends to introduce a fundamental change to the certificate of incorporation or to enter

144. See Fried Frank, supra note 51, at 1-5 (discussing the defensive measures available to French target companies before and after the transposition of the European Directive on takeovers, and mentioning that the reforms have allowed French companies a wider variety of takeover defenses); See also Franck de Vita, Understanding the Rules Governing Public Take Over Bids in France, J. JAPANESE INST. INT'L BUS. L. (2003), available at $\mathrm{http}: / / \mathrm{www}$.whitecase.com/Publications/Detail.aspx?publication=17 (examining the defensive measures a French target can implement before the adoption of the new takeover regulations).

145. See ERCML, supra note 11, art. 327(c) ("Considering equality and equal opportunities between the owners of the securities subject to the tender offer as well as between the persons concerned with the tender offer.").

146. Id. 
into a merger agreement with another company. ${ }^{147}$ In both cases, the price of the offer must be as at least equal to the highest price paid in a tender offer during the twelve months prior to launching this offer, and the consideration must be paid in cash. ${ }^{148}$

Although this backend compulsory tender offer provides minority shareholders an exit from the corporation at a fair price, such protection is illusory. This mechanism increases the free-rider problem as it allows minority shareholders to exit the corporation after a year of the successful takeover of the corporation. In addition, the requirement that the consideration be in cash places a heavy burden on the acquiror, who may find it difficult to provide the amount of cash required to complete the deal. ${ }^{149}$ This may generally discourage takeovers. Furthermore, the provisions only grant minority shareholders the right to "request" that the EFSA oblige the controlling shareholder to launch a compulsory tender offer. The discretionary power of the EFSA, which is neither entirely independent nor fully competent, is questionable.

Because part of protecting minority shareholders is mitigating agency costs and balancing the interests of the different constituencies, it is reasonable to also give the controlling shareholder the right to squeeze-out minority shareholders in the wake of a successful takeover. Contrary to the compulsory tender offer of the previous case, this squeeze-out technique would encourage takeovers.

Following the implementation of the European Directive in France, the French regulations introduced this new squeeze-out procedure. ${ }^{151}$ The squeezeout provision allows the holder of 95 percent of the company's capital to buy out minority shareholders within three months of the lapse of the main offer and at the same price of that offer. ${ }^{152}$ Moreover, unlike the former squeeze-out rules that required the consideration to be only in cash, the new squeeze-out

147. Id. art. 357.

148. Id. art. 358.

149. A liquidity problem is usually associated with the high concentration of corporate ownership. See Frank Heflin \& Kenneth W. Shaw, Blockholder Ownership and Market Liquidity, 35 J. Fin. \& QUANTITATIVE ANALYSIS 621 (2000).

150. See supra Part III.D.2.

151. The Bahraini Takeover Module has adopted a close approach to the Egyptian compulsory offer under which a holder of 95 percent of the company's capital has to offer to buy out minority shareholders within three months of the main offer and at the higher price paid during the offer period or within three months prior to its commencement. See Bahraini Takeovers, Merger, and Acquisitions Module, Central Bank of Bahrain, vol.6, art. 3.4 (Bahr.).

152. Décision du 28 Septembre 2006 de règlement général de l'Autorité des Marchés Financiers [Decision of September 28, 2006 concerning the Adaptation of the General Regulations of the Autorité des Marches Financiers], JouRnal OfFICIEL DE LA RÉPUBLIQUE FranÇAiSe [J.0.] [OFficlal GAZETTE OF FRANCE], Sept. 28, 2006, art. 237-14 \& -15. See also HERBERT SMITH LLP, IMPLEMENTATION OF THE EU TAKEOVERS DIRECTIVE IN FRANCE 2-3 (2006), available at http://www.herbertsmith.com/NR/rdonlyres/0507455E-0862-4A43-ACD434E595EF5B79/2828/5770FrenchBriefingD3.pdf. 
provisions provide that the bidder may offer securities with a full cash alternative in consideration for the minority shares. ${ }^{153}$

To summarize, the Egyptian takeover regulations have been unsuccessful because they negate the purpose for which they were enacted: to encourage takeovers. ${ }^{154}$ In addition to the reasons related to the difference in motivation and the lack of competent institutional framework, the failure may also be attributed to the following reasons: 1) the mandatory tender offer increases the cost of takeovers; 2) the omission of the breakthrough rule undermines the effect of the non-frustration rule and empowers the incumbent controlling shareholder; 3) as they empower the incumbent shareholders, the regulations do not provide proper protection to minority shareholders. ${ }^{155}$ Thus, the primary beneficiaries of the current takeover regulations are the incumbent controlling shareholders, while minority shareholders are inadequately protected and acquirors are poorly positioned.

\section{The Mobinil Case: A Practical Example on the Failure of the Transplant}

The Mobinil case was the first application of the new Egyptian takeover regulations in the Egyptian courts. The case involved a long dispute between France Telecom (FT) and Orascom Telecom (Orascom) over the control of Mobinil Telecommunications (Mobinil), a privately held corporation established solely for the control of the Egyptian Company for Mobile Services (ECMS.) Upon enforcing an arbitration award to acquire Mobinil, FT triggered the mandatory tender offer rule that required it to launch an offer to all the outstanding shareholders of the ECMS. Eventually, FT failed to take over ECMS in part due to blurred interpretations of the regulations and in part due to the EFSA's failures.

\section{a. Institutional Incompetence: Court Jurisdiction and the EFSA's Behavior}

The Mobinil case drew attention to the conflict of jurisdiction between the administrative courts and the economic courts, which was eventually settled in favor of the administrative courts. ${ }^{156}$ Without questioning the capacity of the administrative courts to hear this kind of disputes, ${ }^{157}$ the nature of the court - as

153. Issuers and Financial Disclosure, supra note 41, art. 237-14 \& -15; See also HERBERT SMITH LLP, supra note 152, at 2-3.

154. See supra Part III.

155. See supra Part III.

156. See Case no. 12149/2010/Supreme Administrative Court (Egypt).

157. The Egyptian Council of States is a well-established institution that is known for the aptitude of its justices. As a public law court, the way the judges handle cases may be affected, which may not fit the peculiar nature of commercial disputes. 
a public law court inexperienced in commercial transactions - undoubtedly impacted its decisions. For example, to nullify FT's tender offer the court rested, inter alia, upon the EFSA's failure to comply with the requirements of Article $366,{ }^{158}$ which required the EFSA to promptly notify the Egyptian Exchange upon its approval of the filing of any tender offer and its prospectus. This procedure allows the shareholders enough time to make up their minds about the offer by making information available to the public even before the EFSA announces its approval of the offer. Despite the fact that the regulations do not specifically provide for a remedy for such a violation, the court found that nullifying the offer is the proper remedy. ${ }^{159}$ However, the court ignored the fact that by nullifying the offer in this case, the court would punish the offeror (FT) for the EFSA's mistake. As a court of public law, the court tends to protect the public interest even though the dispute involves private parties. This is especially true given the fact that shareholders would have at least twenty days to examine the offer and decide upon it, ${ }^{160}$ which is more than enough time to ensure they are well informed.

Aside from the court's decision, the EFSA's negligence and failure to comply with the law underscores its incompetence. The main inconvenience in this case was caused by the EFSA's paradoxical behavior throughout the dispute. Over the course of the dispute, FT and its affiliates presented four tender offers. Three of which were rejected by the EFSA on basis of breaching the principles of equality and equal opportunities for the target's shareholders and because the EFSA did not find a plausible reason to accept a lower price for the mandatory tender offer for the ECMS shareholders than the price determined by the arbitration award for the Mobinil shares. ${ }^{161}$ However, the EFSA had approved the fourth tender offer although its price was still lower than the price determined by the arbitration award. The EFSA based its approval of the fourth offer on an excess cash flow in Mobinil resulting from the accumulation of dividends, which are only paid to Mobinil shareholders. In addition, ECMS had an agreement to pay Mobinil one and a half percent of its total revenues against the latter's managerial services. Combined, these made up the difference in price between the mandatory tender offer and the arbitration award price. ${ }^{162}$

The EFSA's justifications for its change in position are justifiable because even though Mobinil is an empty shell corporation established to

158. ERCML, supra note 11, art. 366.

159. Case no. 12149/2010/Supreme Administrative Court 53 (Egypt).

160. See ERCML, supra note 11, art. 341; The term of the tender offer should not be less than twenty days in cases where the board of the target corporation is bound to consult an independent advisor and ten days otherwise. ERCML, supra note 11, art. 341.

161. Case no. 12149/2010/Supreme Administrative Court 5 (Egypt) (an arbitration award was given before the case was brought to court, which determined that the fair price of Mobinil shares was 273 EGP).

162. Case no. 12149/2010/Supreme Administrative Court 5-6 (Egypt). 
control ECMS, it is a separate entity that may acquire its own assets or liabilities independently from ECMS. These assets may cause its share value to diverge from ECMS's share value. Given this, the EFSA's earlier insistence that FT submits a mandatory tender offer at the same price of the arbitration award price appraising Mobinil's shares is not reasonable. If the EFSA understood this hypothesis, its decisions to reject the three previous offers requiring that the price of FT's mandatory offers be the same as the arbitration price are not justified. Instead, the EFSA could have rejected the offers on the basis of unfair price requiring FT only to increase the price of its mandatory offers.

The EFSA's inconsistent behavior went beyond a mere lack of comprehension of the takeover regulations provisions. Defending its rejection of FT's third offer, the EFSA partially rested its decision upon the prohibition of submitting tender offers from the same bidder within a prescribed period as stipulated by the Egyptian takeover regulations. Indeed, Article 355 prohibits the same bidder from submitting another offer within six months from the date of submitting the original tender offer, unless otherwise permitted by the EFSA. ${ }^{163}$ Despite the fact that the EFSA had expressly used this Article to reject FT's third offer, it approved the fourth offer only five days after rejecting the third offer. Arguably, the EFSA did not violate the provisions of the law by approving the submission of the fourth offer. ${ }^{164}$ Rather, it is the inconsistency in its behavior that is questionable in this specific instance.

The EFSA's misconstruction of the provisions of the Egyptian takeover regulations, along with its non-compliance and paradoxical decisions throughout the case are all too apparent. In part this owes to the inexperience of the EFSA's staff and in part to the nascence of the takeover regulations themselves and their vagueness.

\section{b. Legal Debacles Triggered by the Case}

The Mobinil case highlights several problems with Egyptian takeover law. Two examples were already discussed. Whether the takeover procedures and the terms of such procedures are binding on the EFSA, and, if so, the lack of a specified remedy for the EFSA's nonconformity with such terms as in the

163. ERCML, supra note 11 , art. 355.

164. According to the court, this provision had been repeatedly violated by FT's second, third, and fourth offers. Moreover, the court explains that the prohibition of this provision applies to the mere filing of a subsequent offer. The court may have misinterpreted the provision, nevertheless. The provision prohibits the submission of a new offer from the same bidder within six months from the "original" offer. This means that the six months period applies to FT's first mandatory tender offer only, especially that all the subsequent offers should be considered invalid because they were presented within six months of the first offer. If this is true, FT's fourth mandatory tender offer should have been considered not violating the prohibition period because it was presented after more than six months from the first and only valid offer. See Alshorbagy, supra note 31, at 34. 
case of Article 366 of the ERCML is one example. The second example involves the correct interpretations of Article 355 regarding the six-month prohibition period on the launching of a mandatory tender offer from the same bidder.

On top of the legal issues tackled in this case, there was the price of the mandatory tender offer that FT had to present to ECMS shareholders. This was a central question in the dispute and the main reason for the rejection of FT's first three offers as well as a major reason to strike down the EFSA's approval of the fourth offer. The regulations stipulate that the price of the mandatory tender offer must be at least equal to the price paid by the acquiror in a previous tender offer during the twelve months prior to the commencement of the tender offer. ${ }^{165}$

In the Mobinil case, there was no previous tender offer to follow in determining the mandatory tender offer price for the ECMS shares. This renders the provision useless. To solve the problem, the EFSA and the court had to look for assistance somewhere else. They found inspiration in the predetermined price of the Mobinil shares as appraised by the arbitration award that gave FT the right to acquire Mobinil in March 2009. There are several issues with relying on the arbitration award price.

While the regulations set forth different requirements, the court in Mobinil determined that the arbitration price was the fair price for the ECMS shares. Relying on this predetermined price creates a predicament for the EFSA and the court if ECMS's value significantly changed; it also raises the question on what basis would FT legally have to pay a price that was unfair to the acquiror or the target. The arbitration price would violate law as it is not the price of a previous tender offer and does not promote the purpose of the law of reaching a fair price for the shares. Alternatively, it is also possible that there would be no predetermined price. In all these scenarios, the EFSA and the court would need to find leeway to bend the provisions of the law in order to apply it as initially intended. ${ }^{166}$

The court's reliance on a predetermined acquisition price is not the only issue. The twelve-month window established by the regulations is too long for determining the tender offer price. ${ }^{167}$ This time period is much too long as

165. ERCML, supra note 11 , art. 354.

166. "In a civil law country like Egypt, courts do not have a legislative role. In other words, courts only apply the law but do not make it. Therefore, a vague provision of law that forces the court to improvise ways to apply the law is deemed inept." See Alshorbagy, supra note 31, at 33 n.97.

167. See Alshorbagy, supra note 31 , at $33 \mathrm{n} .98$ ("The facts of this case took place over three years, far more than the twelve months period. The arbitration award determining the allegedly fair price of the share at 273 EGP in March 2009 may have depended on a previous three, six or even twelve months projections of the company's performance, which clearly makes the 273 EGP an outdated estimation of the fair price in April 2010, when the court rendered its final decision"). 
things can drastically change in a year. In the Mobinil case, this is exemplified by the court's reliance on the arbitration award price and its refusal to consider the accumulated dividends because the price it was using was determined before the creation of the dividends. The court forgot or ignored that the price it used was determined in March 2009, more than a year before it rendered its judgment. It is clear that things can change significantly in a twelve-month period, which is why the period should be shortened.

\section{CONCLUSION}

Legal transplants are common and have been a major source of legal development throughout the world. Watson's premise that legal transplants are socially easy and that the act of copying the law is more important than the legal rule itself is not entirely true. Blind copying of legal rules without adapting them to the legal environment in which they are transplanted may cause the failure of the transplant.

For a legal transplant to be successful, it must serve its purported function. Transplantation is easier when the imported rules have the same motivation in both jurisdictions. When the motivations diverge, a successful transplant is more likely to take place only when the host jurisdiction is equipped with adequate institutions and legal infrastructure that can accommodate the imported rules to serve their new purpose.

Although the modern Egyptian legal system is inspired by the French legal system, the transplantation of French takeover regulations in Egypt has not been successful. This failure is due to the incompatibility of the French regulations with the Egyptian legal environment and economic policy. It also is due to the failure of the Egyptian authorities to amend the regulations to match their needs. Subject to certain amendments, the Egyptian takeover transplant may be sustained. 